\title{
Methodological Premises of the Ethics of Social Entrepreneurship: From the Perspective of the Teachings of the Catholic Church
}

Social entrepreneurship is an emerging discipline that provides innovative solutions to social issues such as exclusion, poverty, and unemployment. This field of study combines both economic and social aims. While the practical aspects of social entrepreneurship are valuable, good practice requires a deeper theoretical, ethical, and axiological understanding of social entrepreneurship. This study presents the current lack of knowledge of the normative and axiological determinants of social entrepreneurship due to the commonly held belief that every kind social activity is ethically right. In this context, the author formulates methodological premises of the ethics of social entrepreneurship based on Catholic social teaching.

Key words: social entrepreneurship, normative ethics, axiology, Catholic social teaching.

Social entrepreneurship is a young discipline that seeks innovative solutions to social issues such as exclusion, poverty, and unemployment. It is also a practical science that combines both economic and social goals. Social entrepreneurship achieves this, however, not by using "top-down" approaches to or models of social assistance systems, but by helping the marginalized realize their potential to take initiative through self-employment or self-help. Social enterprises, cooperatives, professional activity or integration centers, and economic associations and foundations that are run and operated by the people who found 
Catholic social teaching

them or members of a community are all concrete examples of the "bottom-up" model.

During the past decades, those involved in public policy and socioeconomics have become increasingly interested in social entrepreneurship; the former believe that social entrepreneurship can compensate for social policies that have heretofore failed, while the latter see social entrepreneurship as an effective means to deliver useful products and social services where the public sector and markets have failed. Social entrepreneurs also seek innovative ways to address and counteract the factors that lead to marginalization and social exclusion of, for example, the disabled, homeless, and unemployed. Although it is important to appreciate the practical aspects of social enterprise, good practice always requires an ever-deeper theoretical and philosophical understanding. ${ }^{1}$ This article presents the lack of knowledge on the ethical and axiological determinants of social entrepreneurship. This aspect of study has been neglected due to the fact that people assume that, insofar as an activity is social in character, it must be ethically correct. From this thinking, it follows that each human action that realizes social goals is morally reasonable and justifiable. In this context, theoretical concepts that satisfactorily describe the normative and axiological determinants of social entrepreneurship are lacking.

Another problem is that authors of already existing, albeit not quite numerous, publications that address the aforementioned issues refer to theories of normative ethics, including Kantianism, utilitarianism, virtue ethics, discourse ethics, postmodern ethics, care ethics, etc. Yet, hypotheses based on Christian personal ethics, which is the fundamental axiological and normative source of Catholic social doctrine, are only marginally present in current research. Therefore, an examination of the normative and axiological potential of Christian personal ethics is necessary when analyzing and developing: 1) professional ethics of social entrepreneurs, 2) regulations to ensure the responsible management of social enterprise, and 3) the axiological determinants of the social economy.

\section{The State of Research}

Very little scholarship on aforementioned topics exists. In fact, no articles on this subject have ever been published in Poland, and the few articles that have been published outside of Poland can be found

Cf. E. Chell, "Social enterprise and entrepreneurship: Towards a convergent theory of the entrepreneurial process," International Small Business Journal, Vol. 25, no.1 (2007): 3-19. 
in scientific or popular science journals. For example, M. Chomątowska presents the fundamentally similar assumptions between the postulates presented by the Catholic Church and the principles on which social economics are based..$^{2} \mathrm{~A}$. Zadroga proves a similar thesis on the axiological relationships between the Church's social doctrine and the social economy. ${ }^{3}$

In literature written in English, more studies examine this problem; however, these studies essentially exclude the perspective of Catholic social doctrine. One issue of the 2012 Journal of Business Ethics was dedicated to the question of the ethics of social entrepreneurship. Within these articles, the authors analyzed the relationships between the disciplines, but they did not refer at all to Catholic personal ethics. In 2016, Chell, Spence, Perrini, and Harris recently published a valuable review, ${ }^{4}$ while F.T. Hannafey presents a valuable overview of earlier literature from the point of view of broader entrepreneurship and ethics. ${ }^{5}$ C. Guo and W. Bielefeld, ${ }^{6}$ M.J. Bouchard, ${ }^{7}$ and S. Hoskinson and D. F. Kuratko ${ }^{8}$ are, among others, the more important authors of monographs on these topics.

In Italian, literature by G. Manzone, one of the leading representatives of social moral theology and Catholic social doctrine in Italy, is worthy of attention. In two of his more recent publications, he presents his ethical reflections on the reality of human labor in the modern market economy, while focusing on the personalistic aspects of work and profession. However, in the first of those monographs, Manzone presents the concept of Corporate Social Responsibility (CSR) as a

2 See M. Chomątowska, "Nauka społeczna Kościoła a gospodarka społeczna," Ekonomia Spoteczna, no. 3 (2013): 67-79.

3 See A. Zadroga, "Ekonomia społeczna i nauczanie społeczne Kościoła. Wzajemne implikacje aksjologiczne," Roczniki Teologiczne, no. 3 (2009): 213-229.

See E. Chell, L. J. Spence, F. Perrini, and J.D. Harris, "Social Entrepreneurship and Business Ethics: Does Social Equal Ethical?," Journal of Business Ethics, Vol. 133 (2016): 619-625.

5 See F. T. Hannafey, "Entrepreneurship and Ethics: A Literature Review," Journal of Business Ethics, Vol. 46, no. 2 (2013): 99-110.

$6 \quad$ See C. Guo and W. Bielefeld, Social Entrepreneurship: an Evidence-Based Approach to Create Social Value, (San Francisco: Jossey-Bass and A. Wiley Brand, 2014).

7 See M. J. Bouchard, ed., The Worth of Social Economy: an International Perspective (Brussels: P.I.E. Peter Lang, 2009).

8 See S. Hoskinson and D.F. Kuratko, The Challenges of Ethics and Entrepreurship in the Global Environment, (United Kingdom: Emerald Group Publishing Ltd., 2015). 
platform for dialogue between business ethics and social doctrine of the Church. H. Alford, G. Rusconi, E. Monti have also undertaken this research $^{9}$ and demonstrated the Church's social thought's contribution to the conceptualization of CRS as well as many practical applications. They all arise from ethical and anthropological principles.

Numerous publications in German are devoted to the social aspects Catholic social teaching of management, as evidenced by the tradition of ordoliberalism and the development of a model of a social market economy. J. Wiemeyer ${ }^{10}$ and A. Suchanek ${ }^{11}$ have written on the topic of the ethical dimension of entrepreneurship and the economy. The slightly older but very valuable work of P. H. Werhahn presents the entrepreneur's subjectivity in the social market economy from the perspective of the Church's social doctrine. ${ }^{12}$ These studies begin by considering the origin of the idea of an entrepreneur and his role in a freemarket economy and ends with an attempt to define an anthropological model of an entrepreneur.

\section{A Justification for a Normative Axiological Analysis of Social Entrepreneurship}

A social entrepreneur acts on two levels: the interior (psychological, moral, and spiritual) level and the exterior (material and physical) level. The first level makes it possible to describe, interpret, and evaluate his behavior from the point of view of his attitudes (personal qualities), moral values and norms, and the spiritual and religious inspirations from which his initiatives originate. The second level make it possible to refer to the way that an entrepreneur organizes his enterprise in order to achieve his objectives. In practice, these two dimensions are closely linked, since a social entrepreneur must have both a source of internal motivation that will determine the direction of his endeavors and stimulation for the creativity he needs to fulfill his role. At the same, an entrepreneur must act professionally in order

9 See H. Alford, G. Rusconi, and E. Monti, Responsabilità sociale dimpresa e dottrina sociale della chiesa cattolica (Milano: Franco Angeli, 2004).

See J. Wiemeyer, "Etyka przedsiębiorstwa w chrześcijańskiej perspektywie społeczno-etycznej," in Społeczna odpowiedzialność gospodarki. Perspektywa interdyscyplinarna, ed. S. Fel (Lublin: Wydawnictwo KUL, 2014).

11 See A. Suchanek, Ökonomische Ethik, $2^{\text {nd }}$ Edition (Tübingen: UTB, Stuttgart, 2007).

12 P.H.Werhahn, Der Unternehmer. Seine ökonomische Funktion und gesellschaftspolitische Verantwortung (Trier: Paulinus, 1990). 
to organize the material resources that he needs to efficiently and effectively achieve his economic and social goals.

For the reasons mentioned above, studies that involve normative and axiological analyses are necessary to provide a better understanding of social entrepreneurship. Moreover, cases of fraud or even financial and economic crimes that arise in social entrepreneurship demonstrate that this sphere of human activity also requires deeper ethical reflection. Until now, however, the principles of ethical behavior, which could constitute an industry code of ethics for social entrepreneurship and aid in resolving moral dilemmas, have not been sufficiently developed. Likewise, an inventory of professional virtues for social entrepreneurs has not been sufficiently taken. Furthermore, as specific organizations, social enterprises need to develop the right understanding of socially responsible stakeholder management. Finally, the social economy itself is dependent on the values that are only intuitively perceived and not clearly indicated and described in the literature on this subject.

As A. Lewicka-Strzałecka points out: "An important argument in favor of formulating moral principles that regulate the behavior of the representatives of specific professions is the fact that a great number of the general values and norms of conduct formulated on the basis of general ethics do not resolve moral dilemmas that are specific to particular professions. Certainly, one of the basic purposes of professional ethics is to help resolve such dilemmas. General ethics points to certain values, but it does not say what needs to be done when these values conflict with each other. [...] The principles of professional ethics should fulfill the general mission, role, or function of a given occupation for the good of society as a whole. This mission should also determine the basic values for the profession, the fidelity to which determines the profession's moral identity." 13

The research that the author of this article proposes is novel because it considers Christian personal ethics in: 1) developing professional ethics of social entrepreneurs, 2) creating a model of principles for responsible social enterprise management, and 3) identifying and describing the key values of the social economy. This, therefore, is a study in business ethics that takes into account a theologically moral viewpoint based on the Christian vision of Catholic social doctrine.

13 A. Lewicka-Strzałecka, Etyczne standardy firm $i$ pracowników (Warsaw: Wydawnictwo Instytutu Filozofii i Socjologii PAN, 1999), 30-32. 
Catholic social teaching

\section{Reasons for a Moral and Theological Analysis of Social Entrepreneurship}

The human person is at the center of Catholic social doctrine. For this reason, the Church "intends to offer a contribution of truth to the question of man's place in nature and in human society," ${ }^{14}$ as an expression of its "solidarity, respect and affection for the whole human family." 15 To this end, the Church enters into a dialogue with humanity about fundamental problems and brings "to mankind light kindled from the Gospel, and puts at its disposal those saving resources which the Church herself, under the guidance of the Holy Spirit, receives from her Founder. For, the human person deserves to be preserved, and human society deserves to be renewed." 16

One of the goals of the Church's social doctrine is a "friendly dialogue with all branches of knowledge."17 In entering into this dialogue, the Church's main intention is to inspire and imbue social life with the values of the Gospel. On the one hand, the Church encourages other scientific disciplines to be open to the values and norms presented by Catholic social teaching and, consequently, to a "broader horizon aimed at serving the individual person who is acknowledged and loved in the fullness of his or her vocation." 18 This means that "the Church does not intervene in technical questions with her social doctrine, nor does she propose or establish systems or models of social organization. This is not part of the mission entrusted to her by Christ. The Church's competence comes from the Gospel: from the message that sets man free, the message proclaimed and born witness to by the Son of God made man." 19

Conversely, because the Church enters into a dialogue, social of the Church must also be open to other scientific disciplines. This "attentive and constant openness to other branches of knowledge makes the Church's

$14 \quad$ Pontifical Council for Justice and Peace, Compendium of the Social Doctrine of the Church (Vatican City, Italy: Libreria Editrice Vaticana, 2005), 14. Ibid, 18.

Second Vatican Council, Pastoral Constitution on the Church in the Modern World: Gaudium et spes (Vatican City, Italy: Libreria Editrice Vaticana, 1965), 3. Hereafter GS.

See Pontifical Council for Justice and Peace, Compendium, 76-78.

John Paul II, Encylical Letter: Centesimus annus (Vatican City, Italy: Libreria Editrice Vaticana, 1991), 59.

Pontifical Council for Justice and Peace, Compendium, 68; see John Paul II, Encyclical Letter Sollicitudo rei socialis (Vatican City, Italy: Libreria Editrice Vaticana, 1987), 41. 
social doctrine reliable, concrete and relevant. Thanks to the sciences, the Church can gain a more precise understanding of man in society, speak to the men and women of her own day in a more convincing manner and more effectively fulfill her task of incarnating in the conscience and social responsibility of our time, the word of God and the faith from which social doctrine flows." ${ }^{20}$ One of the areas of human knowledge that been a source of increasing interest on the part of the Church is social science. The reason the Church is so open to the social sciences is because it is convinced that, if a person is searching for the truth about man and the surrounding world, then one can not exclude any field of knowledge from this process: "The Church recognizes and receives everything that contributes to the understanding of man in the ever broader, more fluid and more complex network of his social relationships. She is aware of the fact that a profound understanding of man does not come from theology alone." ${ }^{21}$

What the Church offers all people can be called an "an integral and solidary humanism" ${ }^{22}$ because it is a humanism that corresponds with the idea of God's love for every human being and the calling of all people to unity as children of one Father." 23 At the same time, the realization of the assumptions of such humanism will "creat[e] a new social, economic and political order, founded on the dignity and freedom of every human person, to be brought about in peace, justice and solidarity. This humanism can become a reality if individual men and women and their communities are able to cultivate moral and social virtues in themselves and spread them in society. 'Then, under the necessary help of divine grace, there will arise a generation of new men, the moulders of a new humanity." 24

As Ireneusz Mroczkowski emphasizes: "The most important methodological task in creating [...] moral theology remains a critical dialogue between faith and the practical reason of ethics that also takes into account the efficacy of God's grace as well as the biological, psychological, and social conditioning of modern man. The hardest methodological task is to defend theology from modern human sciences' reductionist view of man, which is equally suspicious of biblical

\footnotetext{
$20 \quad$ Pontifical Council for Justice and Peace, Compendium, 78.

$21 \quad$ Ibid, 78.

22 Pontifical Council for Justice and Peace, Compendium, 19.

23 See Second Vatican Council, Dogmatic Constitution on the Church: Lumen Gentium (Vatican City, Italy: Libreria Editrice Vaticana, 1964), 1.

24 Pontifical Council for Justice and Peace, Compendium, 19; see Second Vatican Council, GS, 30.
} 
Catholic socia teaching

moral truth and of the ability of ethics to develop and defend objective human values." 25

Considering the scope of the Church's social doctrine's competence, it is necessary to point out the merit of analyzing entrepreneurship from a moral and theological point of view. In the light of Revelation, entrepreneurship can be interpreted as the calling of every human being. The act of creation is the source of this truth; for, through creation, man was bestowed with reason (and creativity as an aspect of reason), free will, and the ability to love. Thus, God created man to be intrinsically entrepreneurial. This pertains mainly to the theological premises of entrepreneurship, and it is from here that theological questions about entrepreneurship arise. Therefore, an analysis of entrepreneurship from the point of view of Catholic social teaching is warranted. Furthermore, since the Catholic Church has had global aspirations since its inception, and given the present reality of globalization, innovative thinking about entrepreneurship is worth considering in light of Catholic tradition.

\section{Conclusion}

One of the key elements of responsible implementation of the mechanisms of social entrepreneurship is the proper form of the norms and the values that condition it. The social teaching of the Church can make a valuable and original contribution to defining and understanding these normative and axiological determinants.

All social doctrine, including the social doctrine promulgated by the Catholic Church and the social doctrine that underlies axiological social enterprise, is based and developed on the principle of the inviolable dignity of the human person. This personalistic approach is the foundation on which all other principles and content of social science rely, particularly: the common good, subsidiarity, and solidarity. Social entrepreneurship promotes the creation of social structures that affirm the value of every human person and enable each person to fully participate in social life. For this reason, social entrepreneurship is a good example of the practical application of the principle of personalization (which is at the heart of the Church's social teaching) in shaping socio-economic life.

It is possible to indicate the motivations and goals that are characteristic of social entrepreneurship as well as the means of their

25 I. Mroczkowski, Teologia moralna. Przedmiot. Definicja. Metoda, (Płock: Płocki Instytut Wydawniczy, 2011), 5-6. 
realization: "Social economics is [...] first of all the specific approach of individual persons and institutions to social reality. Social economics also concerns the attitudes of individuals and institutions toward their own problems (i.e., acting rather than demanding), the way these problems are resolved (collectively rather than individually), and their goals (the common good rather than the group's narrow interests). These actions are greatly based on solidarity and cooperation, rather than on particularism and competition." 26

Catholic social teaching

It is impossible to fully understand (and work effectively in) social entrepreneurship without considering the key principles and values of social life. Literature on this subject primarily discusses solidarity and subsidiarity, entrepreneurship and commitment, prudence and responsibility, and self-reliance and empowerment. However, it is worth analyzing (and eventually expanding) this aforementioned set of values and principles to include those referred to in the social doctrine of the Church. For, by taking up similar issues, both fields can come together not only on the subject level, but also on the level of their deepest principles (i.e., their axiological assumptions). In this way, both areas would be mutually enriched. It is always important to base all efforts on a strong axiological foundation; for, with this foundation in place, one can justifiably hope to realistically build up the common good, a more united world, and, in a broader sense, the civilization of love.

This interdisciplinary approach will make it possible to develop ethics as both a discipline of philosophy and moral theology, both of which concerns research in the fields of Catholic social teaching and the economy, and for which the essential aim is a deeper understanding of entrepreneurial behavior and the axiological determinants of the social economy. The role of entrepreneurship in socio-economic progress is very important for the development of civilizations. Without sound theory, good and effective practice is impossible. For this reason, the results of normative and axiological studies will directly affect whether the goals of social entrepreneurship will be achieved.

$26 \quad$ P. Frączak and J. J. Wygnański, eds., Polski model ekonomii społecznej. Rekomendacje dla rozwoju. Zaproszenie do dyskusji (Warsaw: Fundacja Inicjatyw Społeczno-Ekonomicznych, 2008), 15. 


\section{METODOLOGICZNE PRZESŁANKI ETYKI PRZEDSIĘBIORCZOŚCI SPOŁECZNEJ: PERSPEKTYWA KATOLICKIEJ NAUKI SPOŁECZNEJ}

Catholic social teaching

Przedsiębiorczość społeczna poszukuje innowacyjnych rozwiązań takich kwestii społecznych, jak wykluczenie społeczne, ubóstwo czy bezrobocie. Jest to umiejętność łączenia celów gospodarczych i społecznych. Doceniając praktyczne aspekty tej formy działalności, nie należy jednocześnie zapominać, że dobra praktyka zawsze wymaga teoretycznego - w tym etycznego oraz aksjologicznego - pogłębienia. Autor artykułu stawia tezę o niezadowalający stanie wiedzy właśnie na temat etycznych i aksjologicznych uwarunkowań przedsiębiorczości społecznej. Jego zdaniem, ten aspekt badań jest zaniedbany, ze względu na błędne przekonanie, że jeśli jakaś działalność ma charakter społeczny, to jednocześnie oznacza to, że jest etycznie poprawna. W tym kontekście autor formułuje w niniejszym artykule metodologiczne przesłanki wypracowania koncepcji etyki przedsiębiorczości społecznej w perspektywie katolickiej nauki społecznej.

Słowa kluczowe: przedsiębiorczość społeczna, etyka normatywna, aksjologia, katolicka nauka społeczna.

\section{Bibliography:}

1. Alford, H., G. Rusconi, and E. Monti. Responsabilità sociale dimpresa e dottrina sociale della chiesa cattolica. Milano: Franco Angeli, 2004.

2. Bouchard, M. J., Ed. The Worth of Social Economy: an International Perspective. Brussels: P.I.E. Peter Lang, 2009.

3. Chell, E. "Social enterprise and entrepreneurship: Towards a convergent theory of the entrepreneurial process." International Small Business Journal. Vol. 25, No. 1 (2007): 3-19.

4. Chell, L., J. Spence, F. Perrini, and J. D. Harris. "Social Entrepreneurship and Business Ethics: Does Social Equal Ethical?" Journal of Business Ethics, Vol. 133 (2016): 619-625.

5. Chomątowska, M. "Nauka społeczna Kościoła a gospodarka społeczna." Ekonomia Społeczna, no. 3 (2013): 67-79.

6. Frączak, P. and J. J. Wygnański, Eds. Polski model ekonomii społecznej. Rekomendacje dla rozwoju. Zaproszenie do dyskusji. Warsaw: Fundacja Inicjatyw Społeczno-Ekonomicznych, 2008, 15

7. Guo, C. and W. Bielefeld. Social Entrepreneurship: an Evidence-Based Approach to Create Social Value. San Francisco: Jossey-Bass and A. Wiley Brand, 2014.

8. Hannafey, F.T. "Entrepreneurship and Ethics: A Literature Review." Journal of Business Ethics, vol. 46, no. 2 (2013): 99-110.

9. Hoskinson, S., and D. F. Kuratko. The Challenges of Ethics and Entrepreurship in the Global Environment. United Kingdom: Emerald Group Publishing Ltd., 2015. 
10. John Paul II. Encyclical Letter Sollicitudo rei socialis. Vatican City, Italy: Libreria Editrice Vaticana, 1987.

11. John Paul II. Encylical Letter: Centesimus annus. Vatican City, Italy: Libreria Editrice Vaticana, 1991.

12. Lewicka-Strzałecka, A. Etyczne standardy firm i pracowników. Warsaw: Wydawnictwo Instytutu Filozofii i Socjologii PAN, 1999, 30-32.

13. Manzone, G. La responsabilità dell'impresa. Business Ethics e Dottrina sociale della Chiesa in dialogo. Brescia: Queriniana, 2002.

14. Manzone, G. Il lavoro tra riconoscimento e mercato. Brescia: Queriniana, teaching 2006.

15. Manzone, G. Il volto umano delle professioni. Rome: Carocci Editore, 2011.

16. Mroczkowski, I. Teologia moralna. Przedmiot. Definicja. Metoda. Płock: Płocki Instytut Wydawniczy, 2011.

17. Pontifical Council for Justice and Peace. Compendium of the Social Doctrine of the Church. Vatican City, Italy: Libreria Editrice Vaticana, 2005.

18. Second Vatican Council. Dogmatic Constitution on the Church: Lumen Gentium. Vatican City, Italy: Libreria Editrice Vaticana, 1964.

19. Second Vatican Council. Pastoral Constitution on the Church in the Modern World: Gaudium et spes. Vatican City, Italy: Libreria Editrice Vaticana, 1965.

20. Suchanek, A. Ökonomische Ethik, $2^{\text {nd }}$ Edition. Tübingen: UTB, Stuttgart, 2007.

21. Werhahn, P. H. Der Unternehmer. Seine ökonomische Funktion und gesellschaftspolitische Verantwortung. Trier: Paulinus, 1990.

22. Wiemeyer, J. "Etyka przedsiębiorstwa w chrześcijańskiej perspektywie społeczno-etycznej." In Społeczna odpowiedzialność gospodarki. Perspektywa interdyscyplinarna. Edited by S. Fel. Lublin: Wydawnictwo KUL, 2014.

23. Zadroga, A. "Ekonomia społeczna i nauczanie społeczne Kościoła. Wzajemne implikacje aksjologiczne." Roczniki Teologiczne, no. 3 (2009): 213-229. 